\title{
SYNTHESIS OF NOVEL SUBSTITUTED 4-PHENYL-5- PHENOXYMETHYL-3-MERCAPTO-1,2,4-TRIAZOLE (4 H) DERIVATIVES AS POTENTIAL ANTI-ULCER AGENTS
}

\author{
Lina Perekhoda ${ }^{1}$, Idibeg Kadamov ${ }^{2}$, Narzullo Saidov ${ }^{2}$, Victoriya Georgiyants ${ }^{1}$ \\ ${ }^{1}$ National University of Pharmacy, Kharkov \\ ${ }^{2}$ Tajic National University, Dushanbe
}

\begin{abstract}
In this work, the series of new 4-phenyl-5-4-(R)-phenoxymethyl-1,2,4-triazole-3-ylthio-1-( $\left.\mathrm{R}^{1}\right)$-acetophenones have been synthesized by alkylation of correspondent 4-phenyl-5-phenoxymethyl-3-mercapto-1,2,4triazoles $(4 \mathrm{H})$ with the $a$-chloroacetophenones. The structure of the synthesized substances has been proven by NMR spectra. High possibility of anti-ulcer and anti-helicobacter activity was determined by the PASS program. Molecular docking and anti-ulcer screening of new 1,2,4-triazole $(4 \mathrm{H})$ derivatives on the acute alcohol-prednisolone model NSAID-induced ulcers in rats has been performed.
\end{abstract}

Keywords: synthesis, anti-ulcer activity, docking study, alkylation, pharmacological activity prognosis, derivatives 1,2,4-triazole

\section{INTRODUCTION}

The 1,2,4-triazole $(4 H)$ derivatives, which are used in this study, play an important role in medicinal chemistry and are useful templates for further development through modification or derivatization to design more potent biologically active compounds. 1,2,4-Triazole is an important group in heterocyclic compounds because of wide range of therapeutically importance used in a wide variety of medicines e.g. Ribavarin, (an antiviral drug), Rizatriptan (an antimagraine), Alprazolam (an anxiolytic), Vorozole, Letrozole and Anastrozole (antitumoral) are

\footnotetext{
Address for correspondence:

Lina Perekhoda

National University of Pharmacy,

53 Pushkinska Str.,

61002 Kharkiv, Ukraine

e-mail:perekhodalina@mail.ru
}

Received: August 27, 2015

Accepted: December 1, 2015 some examples of these drugs (1). A large number of research has been carried out on 1,2,4-triazole $(4 H)$ and their derivatives, which have proved the pharmacological importance of these heterocyclic nucleus (2-6). Although they have been known from long ago as biologically active, their varied biological features are still interesting for science. An additional advantage of this group of substances is the relative simplicity of their synthesis. Previously, we have synthesized derivatives of 3-mercapto-1,2,4-triazole containing in 5 position phenoxymethyl and in 4 position benzyl or allyl residues (7-8). A number of them have shown interesting pharmacological properties, one of them has anti-ulcer activity (7-8). We were interested to see how the replacement of benzyl or allyl residues to phenyl in 4 position influences on the pharmacological properties. The purpose of this work is the synthesis of new derivatives of $1,2,4(4 \mathrm{H})$ triazoles, prediction of their probable anti-ulcer activity by the computer program PASS, conducting the docking study, and comparison of their anti-ul- 
cer activity in vivo on the acute alcohol-prednisolone model NSAID-induced ulcers in rats.

\section{MATERIALS AND METHODS}

Synthetic strategy of this study is the structure modification of 1,2,4-triazole $(4 H)$ ring scaffolds in the positions 1, 2 and 5 with the aim of obtaining more potent pharmacologically active compounds. All research chemicals were purchased from the Sigma-Aldrich (USA) and used as such for the reactions. Several key types of the reactions were generally used us that allowed to obtain new started mercaptotriazoles $\mathbf{6} \boldsymbol{a}-\boldsymbol{b}(9)$. The synthesis of $\mathbf{6} \boldsymbol{a}-\boldsymbol{b}$ was carried out from the corresponding phenols $\mathbf{1} \boldsymbol{a}-\boldsymbol{b}$ due to Scheme 1.

Resulting from the alkylation of ethyl chloroacetate and subsequent hydrazinolysis substituted phenoxyacetic acid hydrazides $\mathbf{3} \boldsymbol{a}-\boldsymbol{b}$ were involved into interaction with phenylisothiocyanates 4 with vigorous stirring in ethanol. Reactions were monitored by thin layer chromatography carried out using pre-coated silica gel plates (E. Merck and Co., Darmstadt, Germany).

The reaction mixture was heated to reflux, cooled and the precipitate of formed substituted phenylthiosemicarbazides $\mathbf{5} \boldsymbol{a}-\boldsymbol{b}$ was filtered out and dried. Phenylthiosemicarbazides synthesized were cyclized in the presence of alkali. The reaction mixture was refluxed. After cooling, the solution was acidified with hydrochloric acid to $\mathrm{pH}=3-4$. The resulting precipitate was the corresponding 4-aryl5-phenoxymethyl-3-mercapto-1,2,4-triazoles $\mathbf{6} \boldsymbol{a}$ - $\boldsymbol{b}$ was filtered, washed with water and dried. The existence of thiol-thione tautomerism is known for the compounds $\mathbf{6} \boldsymbol{a}-\boldsymbol{b}$, and thione forms predominates according to the data of NMR spectroscopy. To further transformations mercaptotriazoles synthesised $\boldsymbol{6} \boldsymbol{a}-\boldsymbol{b}$ were alkylated by chloroacetophenones $7 \boldsymbol{a}-\boldsymbol{f}$ in a homogeneous base catalysis conditions, resulting to the compounds 4-phenyl-5-4-(R)-phenoxymethyl-1,2,4-triazole-3-ylthio-1-( $\left.\mathrm{R}^{1}\right)$-acetophenones $\boldsymbol{8 a}-\boldsymbol{f}$ (Scheme 1). Structures of compounds were confirmed via their spectral data. The ${ }^{1} \mathrm{H}$ NMR spectra were obtained on an NMR Spectrophotometer (Bruker Avance II 200 NMR) using DMSO-d6 as a solvent. Chemical shifts were expressed in parts per million relative to TMS as an internal standard.

All substances $8 \boldsymbol{8}-\boldsymbol{f}$ have been tested for compliance with Lipinski's rule of five (a set of physical<smiles>[R]c1cccc(O)c1</smiles><smiles>[R]c1cccc(OCC(=O)NNC(=S)Nc2ccccc2)c1</smiles><smiles>[R]c1ccc(C(=O)CSc2nnc(COc3ccccc3)n2-c2ccccc2)cc1</smiles>

Scheme 1 
and chemical properties meet modern requirements that apply to new compounds under testing their biological activity) by the computer program ACD / Labs (10). The probability of anti-ulcer activity of the newly synthesized substances was simulated by the computer program PASS (Prediction of Activity Spectra for Substances) (11).

Molecular docking and anti-ulcer screening of new 4-phenyl-5-4-(R)-phenoxymethyl-1,2,4-triazole-3-ylthio-1- $\left(\mathrm{R}_{1}\right)$-acetophenones have been performed. Docking was carried out by taking of proteins membrane histamine $\mathrm{H}_{2}$ receptor (PDB ID: 1U19), human gastric pathogen helicobacter pylori (PDB ID: 3 UX4) and the human microsomal prostaglandin E enzyme synthase 1(MPGES1) domains (PDB ID: 3DWW) as a targets for anti-ulcer activity (12-15). Since Black et al. first defined the $\mathrm{H}_{2} \mathrm{R}$ receptor and its involvement in gastric acid secretion, $\mathrm{H}_{2} \mathrm{R}$ antagonists (e.g., cimetidine, ranitidine, famotidine) have been developed and used clinically as antiacid secretagogues. These histamine $\mathrm{H}_{2} \mathrm{R}$ antagonists have revolutionized the treatment of peptic ulcers with their prominent therapeutic effects. Prostaglandins have anti-secretory effect on gastric acid and protect the lining of the stomach from the damaging effects of the acid. Therefore, ligands which can prevent rapid metabolic conversion prostaglandins into inactive products may be used for treating of NSAID-induced ulcer. Half the world's population is chronically infected with Helicobacter pylori, causing gastritis, gastric ulcers and an increased incidence of gastric adenocarcinoma. Therefore, human gastric pathogen helicobacter pylori (PDB ID: 3UX4) also can be used as target. The docking simulations were performed by the SCIGRESS program (16). Fast docking method, in which receptor is rigid and ligands are flexible, was adopted and binding energy values were compared with each other.

All chemical structures $\mathbf{8} \boldsymbol{a}$ - $\boldsymbol{f}$ were generated using ISIS DRAW 4.0 software. The docking study was performed using Scigress Explorer 7.7 installed on a single machine running on a $3.4 \mathrm{GHz}$ Intel Core 2 Duo Processor with 1GB RAM and 160 GB Hard Disk with Windows XP as Operating System. Ligands structures $8 \boldsymbol{a}-\boldsymbol{f}$ were drawn on Scigress Explorer using standard bond, lengths and angles. The ligands were stored in .csf format. The proteins modeled using the electron crystallographic structure at
3.5A resolution was downloaded from the RCSB Protein Data Bank (PDB ID: 1U19, 3DWW, 3UX4). Before the docking water molecules were removed and hydrogen was added to the crystal structure of proteins. After assigning charge and protonation state final refinement (energy minimization) was done using MM3 force field runs. Energy minimization or complex optimization was done for molecular docking calculations and to optimize geometries within the binding site. Complex optimization gave us ligands with minimum energy pose within the active site cavity of the proteins. At the end of the docking study, the minimum Consensus scores for the best positions for each of ligands were obtained.

Obtained 6 heterocyclic compounds became an object for study concerning anti-ulcer activity (17). The study of anti-ulcer activity of the synthesized compounds was carried out using mongrel white rats of both sexes weighing 180-280 g, which previously were stood in a starvation diet for 24 hours without limitation of drinking water. Acute ethanol-prednisolone gastric ulcer of rats was induced by disposable intragastric administration of ethanol - prednisolone mixture (prednisolone at a dose of $20 \mathrm{mg} / \mathrm{kg}$ and ethanol $(80 \%)$ at the rate of $0.6 \mathrm{ml}$ per $100 \mathrm{~g}$ of rat).

The test substance was administered intragastrically at a dose $(20 \mathrm{mg} / \mathrm{kg})$, a reference drug - ranitidine at a dose $40 \mathrm{mg} / \mathrm{kg}$ in a preventive mode for 1 hour prior to administration ethanol - prednisolone mixture. At the end of the experiment the animals were taken out of the experiment ( 24 hours after administration of ulcerogenic agent) under conditions of euthanasia. The stomachs were removed, cut, washed with saline and conducted macroscopic study of the gastric mucosa. Assessment of intensity of ulcerative lesions and anti-ulcer activity of the preparations was carried out by the state of macroscopic parameters of the mucous membrane of the stomach and gastrointestinal tract, and the intensity of the formation of ulcer:

1. The percentage of animals with ulcers (PA);

2. The average size of ulcers in a group (SU);

3. Ulcer Index (UI);

4. Anti-ulcer activity (AUA, \%).

Furthermore, in the process of analyzing the experimental results, external appearance and general condition of the animals were taken into ac- 
count. Indicators of the state of the gastrointestinal tract and mucous membrane of the stomach, namely a swelling of the stomach and intestines, hyperemia, hemorrhage, edema, folding disorders were assessed for their severity in points:

0 points - there is no sign, 1 points - the sign is weak, 2 points - moderate, 3 points - much.

Ulcerative index and anti-ulcer activity were calculated by the formula:

$\mathrm{UI}=(\mathrm{SU} \times \mathrm{PA}) / 100$

AUA, $\%=100 \%-((\mathrm{UI}(\mathrm{t}) \times 100 \%) / \mathrm{UI}(\mathrm{c}))$, where

$\mathrm{UI}(\mathrm{t})-\mathrm{UI}$ in the group of animals with model pathology, which are treated,

UI (c) - UI in the group of animals with control pathology, which are not treated.

Ranitidine was chosen as the reference drug, the active ingredient of which is $\mathrm{N}$-[2-[[[5[(dimethylamine)methyl]-2-phuranil]thio]aethyl]N'-methyl-2-nitro-1,1-ethendiamine (18). Ranitidine is included in the National Drug Formulary namely the list of drugs for the treatment of peptic ulcer disease and its experimental dose has been taken from the literature (18). The experimental doses of the test substances are corresponded to previously established conditionally therapeutic dose of thiotriazoline.

\section{RESULTS}

All synthesized compounds 4-phenyl-5-(4R-phenoxymethyl-1,2,4-triazole-3-ylthio-1- $\left(\mathrm{R}_{1}\right)$ - acetophenone $8 \boldsymbol{a}-\boldsymbol{f}$ after crystallization from ethanol are white crystalline substances with clear melting points, soluble in organic solvents. Melting points $(\mathrm{mp})$ were determined on a Kofler melting point apparatus. Physical properties and other data are shown in Table 1. The structure of compounds $\mathbf{8 a}-\boldsymbol{f}$ was confirmed by ${ }^{1} \mathrm{H}$ NMR spectroscopy (19). The mercaptogroup proton signal after alkylation disappears in compounds $8 \boldsymbol{8}-\boldsymbol{f}$. The signals of aromatic protons were observed in the ranges 6.75-8.20 ppm. As shown in Table 2, the signals of both methylene groups associated with sulfur and oxygen atom are common and occur. Due to the absence of protons in their surroundings they look like singlet. The signals of methylene groups have been interpreted by us in accordance with the electronegativity of neighboring atoms so - signals at 5.28-5.29 ppm has been attributed to the presence of a group $\mathrm{OCH}_{2}$; at 5.15-5.18 ppm - group $\mathrm{SCH}_{2}$. Methyl groups of the tert-butyl residue are shown on the spectra as a single signal intensity in 9 protons at $1.20-1.25 \mathrm{ppm}$.

We can presume on the base of the data obtained by the computer program PASS that all compounds of this group (8a-f) may exhibit high anti-ulcer probable activity $(\mathrm{Pa})$ by inhibition of histamine $\mathrm{H}_{2 \text {-receptor }}$ (from 0.52 to 0.69 ) and anti-helicobacter activity ( $\mathrm{Pa}$ from 0.50 to 0.65 ), which served as a primary screen and are listed in Table 3. The most promising substance $\boldsymbol{8} \boldsymbol{b}$ (maximum activity index 0.69 ) is observed when introduced into the molecule simul-

Table 1. Yields, melting points and elemental analysis data for new compound synthesized 8a-f

\begin{tabular}{|c|c|c|c|c|c|c|c|c|c|}
\hline & \multirow[t]{2}{*}{$\mathrm{R}$} & \multirow[t]{2}{*}{$\mathrm{R}^{1}$} & \multirow[t]{2}{*}{$\begin{array}{c}\text { Yield, } \\
\%\end{array}$} & \multirow[t]{2}{*}{$\begin{array}{l}\text { M.p., } \\
{ }^{\circ} \mathrm{C}\end{array}$} & \multicolumn{2}{|c|}{ Calculated, \% } & \multirow[t]{2}{*}{ Formula } & \multicolumn{2}{|c|}{$\begin{array}{l}\text { Found, } \\
\%\end{array}$} \\
\hline & & & & & $\mathrm{N}$ & S & & $\mathrm{N}$ & S \\
\hline $8 \mathrm{a}$ & $4-\mathrm{t}-\mathrm{Bu}$ & $\begin{array}{l}3-\mathrm{Cl} \text {; } \\
4-\mathrm{Cl}\end{array}$ & 66,7 & $106-108$ & 7,98 & 6,09 & $\mathrm{C}_{27} \mathrm{H}_{25} \mathrm{Cl}_{2} \mathrm{~N}_{3} \mathrm{O}_{2} \mathrm{~S}$ & 7,99 & 6,17 \\
\hline $8 b$ & $4-\mathrm{t}-\mathrm{Bu}$ & $3-\mathrm{NO}_{2}$ & 76,2 & $82-84$ & 11,15 & 6,38 & $\mathrm{C}_{27} \mathrm{H}_{26} \mathrm{~N}_{4} \mathrm{O}_{4} \mathrm{~S}$ & 11,17 & 6,51 \\
\hline $8 c$ & $\begin{array}{c}\text { 2-i-Pr; } \\
5-\mathrm{Me}\end{array}$ & $4-\mathrm{Br}$ & 67,2 & $115-117$ & 7,83 & 5,98 & $\mathrm{C}_{27} \mathrm{H}_{26} \mathrm{Br} \mathrm{N}_{3} \mathrm{O}_{2} \mathrm{~S}$ & 7,98 & 5,99 \\
\hline $8 \mathrm{~d}$ & $\begin{array}{l}\text { 2-i-Pr; } \\
5-\mathrm{Me}\end{array}$ & $4-\mathrm{Cl}$ & 67,9 & $112-114$ & 8,54 & 6,52 & $\mathrm{C}_{27} \mathrm{H}_{26} \mathrm{ClN}_{3} \mathrm{O}_{2} \mathrm{~S}$ & 8,65 & 6,62 \\
\hline $8 \mathrm{e}$ & $\begin{array}{l}\text { 2-i-Pr; } \\
5-\mathrm{Me}\end{array}$ & $4-\mathrm{CHF}_{2}$ & 75,3 & $88-90$ & 8,03 & 6,22 & $\mathrm{C}_{28} \mathrm{H}_{28} \mathrm{~F}_{2} \mathrm{~N}_{3} \mathrm{O}_{3} \mathrm{~S}$ & 8,13 & 6,34 \\
\hline $8 \mathrm{f}$ & $\begin{array}{l}\text { 2-i-Pr; } \\
5-\mathrm{Me}\end{array}$ & & 63,7 & $152-154$ & 8,15 & 6,22 & $\mathrm{C}_{29} \mathrm{H}_{29} \mathrm{~N}_{3} \mathrm{O}_{4} \mathrm{~S}$ & 8,19 & 6,37 \\
\hline
\end{tabular}


Table 2. 1H NMR spectral characteristics of the synthesized compounds $8 a-f$

\begin{tabular}{|c|c|c|c|c|}
\hline & $\mathrm{Ar}-\mathrm{H}$ & $\mathrm{OCH}_{2}, 2 \mathrm{H}, \mathrm{s}$ & $\mathrm{SCH}_{2}, 2 \mathrm{H}, \mathrm{s}$ & \\
\hline $8 a$ & $6,81-7,98, \mathrm{~m}, 13 \mathrm{H}$ & 5,29 & 5,18 & $1,25, \mathrm{t}-\mathrm{Bu}, 9 \mathrm{H}, \mathrm{s}$ \\
\hline $8 b$ & $6,75-7,84, \mathrm{~m}, 14 \mathrm{H}$ & 5,28 & 5,15 & $1,25, \mathrm{t}-\mathrm{Bu}, 9 \mathrm{H}, \mathrm{s}$ \\
\hline $8 c$ & $7,33-8,05, \mathrm{dd}, 4 \mathrm{H}$ & 5,28 & 5,16 & $\begin{array}{l}3,30, \mathrm{~m}, 1 \mathrm{H}, \mathrm{CH}\left(\mathrm{CH}_{3}\right)_{2} \\
1,20, \mathrm{~d}, 6 \mathrm{H}, \mathrm{CH}\left(\mathrm{C}_{\underline{3}}^{-}\right)_{2}\end{array}$ \\
\hline $8 \mathrm{~d}$ & $7,30-8,20, \mathrm{dd}, 4 \mathrm{H}$ & 5,29 & 5,16 & $\begin{array}{c}3,30, \mathrm{~m}, 1 \mathrm{H}, \mathrm{CH}\left(\mathrm{CH}_{3}\right)_{2} \\
1,21, \mathrm{~d}, 6 \mathrm{H}, \mathrm{CH}\left(\mathrm{CH}_{\underline{3}}^{-}\right)_{2}\end{array}$ \\
\hline $8 \mathrm{e}$ & $\begin{array}{c}\text { 7,33-8,08, dd, } 4 \mathrm{H} \\
6,88-7,30, \mathrm{~m}, 11 \mathrm{H}, \\
\left(2 \mathrm{xh}+\mathrm{CHF}_{2}\right)\end{array}$ & 5,29 & 5,16 & $\begin{array}{l}3,30, \mathrm{~m}, 1 \mathrm{H}, \mathrm{CH}\left(\mathrm{CH}_{3}\right)_{2} \\
1,20, \mathrm{~d}, 6 \mathrm{H}, \mathrm{CH}\left(\underline{\mathrm{H}}_{\underline{3}}^{-}\right)_{2}\end{array}$ \\
\hline $8 \mathrm{f}$ & $6,88-7,51, \mathrm{~m}, 13 \mathrm{H}$ & 5,29 & 5,16 & $\begin{array}{c}3,30, \mathrm{~m}, 1 \mathrm{H}, \mathrm{CH}\left(\mathrm{CH}_{3}\right)_{2} \\
1,20, \mathrm{~d}, 6 \mathrm{H}, \mathrm{CH}\left(\mathrm{CH}_{3}^{-}\right)_{2} \\
4,29,2 \mathrm{H}, \mathrm{t}, 4,34,2 \mathrm{H}^{2} \mathrm{t} \\
\quad\left(\mathrm{OCH}_{2} \mathrm{CH}_{2} \mathrm{O}\right)\end{array}$ \\
\hline
\end{tabular}

Table 3. Compound probable activity and dock score

\begin{tabular}{|l|c|c|c|c|c|}
\hline \multirow{2}{*}{ Com pound № } & \multicolumn{2}{|c|}{ Probable activity $(\mathrm{Pa})$} & \multicolumn{3}{c|}{ Consensus docking score } \\
\cline { 2 - 6 } & $\begin{array}{c}\text { Anti-ulcer } \\
\text { activity }\end{array}$ & $\begin{array}{c}\text { Anti-helico- } \\
\text { bacter } \\
\text { activity }\end{array}$ & 3DWW & 1 U19 & 3 UX4 \\
$8 a$ & 0.52 & 0.65 & $-23,5$ & $-39,9$ & $-14,3$ \\
$8 b$ & 0.69 & 0.62 & $-39,4$ & $-79,3$ & $-15,3$ \\
$8 c$ & 0.58 & 0.63 & $-25,2$ & $-75,2$ & $-15,2$ \\
$8 d$ & 0.55 & 0.62 & $-25,7$ & $-50,5$ & $-15,5$ \\
$8 e$ & 0.62 & 0.64 & $-23,1$ & $-33,5$ & $-13,5$ \\
$8 f$ & 0.61 & 0.61 & $-14,3$ & $-24,3$ & $-14,3$ \\
\hline
\end{tabular}

Table 4. Anti-ulcer activity screening 8a-fon acute alcohol-prednizolon model NSAID-induced ulcers

\begin{tabular}{|c|c|c|c|c|}
\hline $\begin{array}{l}\text { Experimental groups, } \\
(\mathrm{n}=6)\end{array}$ & $\begin{array}{c}\text { Amount of animals } \\
\text { with ulcers in group, } \%\end{array}$ & Average area of ulcers, $\mathrm{MM}^{2}$ & $\begin{array}{l}\text { Anti-ulcer } \\
\text { index }\end{array}$ & $\begin{array}{l}\text { Antiulcer } \\
\text { activity, \% }\end{array}$ \\
\hline Intact control & - & - & - & - \\
\hline Checksum pathology & 100 & $59,5 \pm 2,12$ & 59,50 & - \\
\hline Ranitidine & 100 & $48,5 \pm 2,48^{*}$ & 48,51 & 18,49 \\
\hline $8 a$ & 100 & $45,75 \pm 1,23^{* / * *}$ & 45,75 & 16,60 \\
\hline $8 b$ & 100 & $44,75 \pm 3,69^{* / * *}$ & 44,75 & 21,60 \\
\hline $8 c$ & 100 & $49,89 \pm 3,13^{\star}$ & 39,89 & 20,02 \\
\hline $8 d$ & 100 & $45,83 \pm 1,83^{\star}$ & 45,83 & 16,04 \\
\hline $8 e$ & 100 & $45,25 \pm 2,92^{* / * *}$ & 45,25 & 16,29 \\
\hline $8 f$ & 100 & $59,24 \pm 1,44^{*}$ & 59,45 & - \\
\hline
\end{tabular}

* activity was not significant

The experimental results were processed by mathematical statistics using Student's $t$-test. Significant results are considered $P \leq 0,05$.

Notes: $n$ - number of animals in the group;

${ }^{*}$ Statistically significant differences in relation to the control group of pathology at the significance level $p<0.05$ (by Student's t-test);

${ }^{*}$ Differences are statistically significant in relation to the group receiving ranitidine at significance level $p<0.05$ (by Student's $t$-test). 
taneously tert-butyl substituent and a nitro group (Table 3). All synthesized compounds $8 \boldsymbol{a}-\boldsymbol{f}$ have no violations of Lipinski's rule of five and can be recommended for further research as compounds with favorable physical and chemical properties.

The target proteins structures (PDB ID: 1U19, 3DWW, 3UX4) were docked with new 1,2,4-triazole $(4 H)$ derivatives $8 \boldsymbol{a}$ - $\boldsymbol{f}$ which provided excellent results as were seen by the least values of the dock score in Table 3.

Anti-ulcer activity preliminary screening results for tested compounds at one dose assay are shown in Table 4. The studies found that 5 of the 6 tested substances have anti-ulcer activity at the level of the reference drug ranitidine.

\section{DISCUSSION}

All prescreened ligands 4-phenyl-5-4-(R)phenoxymethyl-1,2,4-triazole-3-ylthio-1-( $\left.\mathrm{R}^{1}\right)$-acetophenones had docking scores in the receptor cavity (1U19) greater than that of ranitidine $(-35.84 \mathrm{kcal} /$ $\mathrm{mol}$ ) indicating that they bind the target better.

Results of the docking have shown that molecule $\boldsymbol{8} \boldsymbol{b}$ has a dock score better in the receptor cavity (1U19) than the others (highest negative dock score 79.3) (Fig. 1).

It means that it can fit well forming the most energetically stable drug receptor complex. The best possible binding modes of the $\boldsymbol{8} \boldsymbol{b}$ at targeted protein's 1 U19 active sites are displayed in Fig. 2.

All tested ligands had docking scores in the receptor cavity (3DWW) down the level of mysoprostol $(-46.51 \mathrm{kcal} / \mathrm{mol})$ indicating that they bind the target better.

When analyzing the docking results it is worth to mention that compounds 1,2,4-triazole $(4 H)$ derivatives $8 a, 8 b, 8 c, 8 d$ and $8 \boldsymbol{e}$ have anti-ulcer activity.

In our research experiment in vivo five derivatives of 1,2,4-triazole (compounds tested $8 \boldsymbol{a}, \boldsymbol{8 b}, \mathbf{8 c}$, $\boldsymbol{8} \boldsymbol{d}$ and $\boldsymbol{8 e}$ ) significantly prevented the gastric acid secretion and gastric-ulcer formation, similar to the ranitidine effect. Our results demonstrate that all tested substances effectively inhibit gastric acid secretion and protect the gastric mucosal layer in a manner similar to that of other $\mathrm{H}_{2} \mathrm{R}$ antagonists.

Compound tested $8 f$ in one-dose primary assay did not show any impressive anti-ulcer activi-

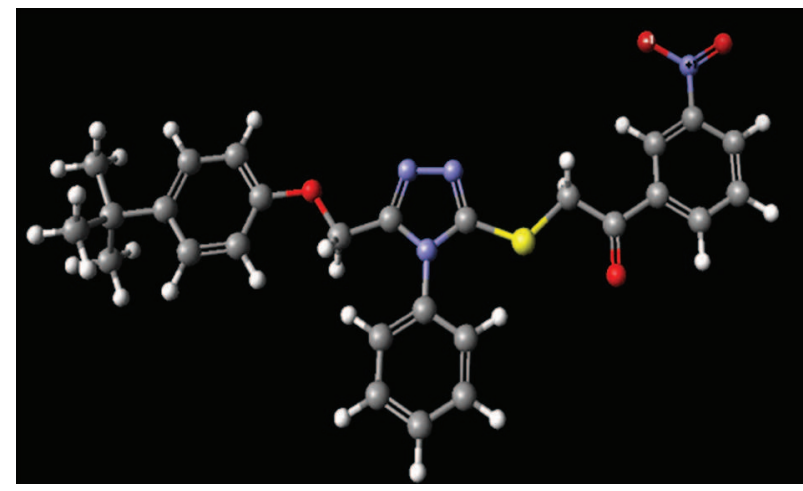

Fig. 1. Ligand $8 b$

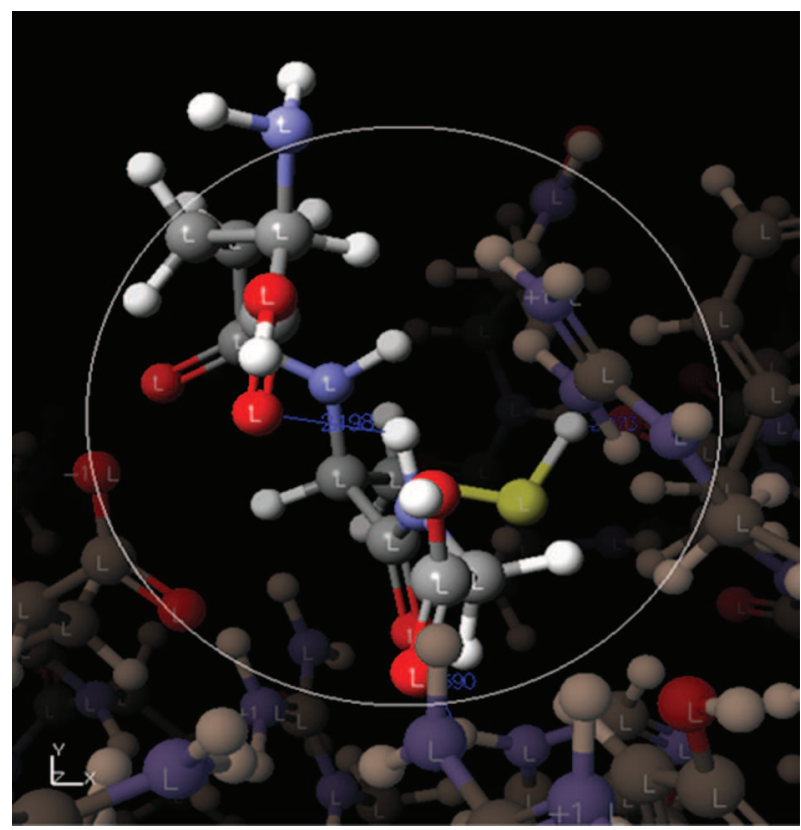

Fig. 2. Protein 31 U19 - Ligand 8 Interaction. Active site amino acid residues are represented as sticks colored according to residue type (Sequence protocol-Karplus and Schultz Flexibility).

ty and therefore can't be considered as prospective anti-ulcer agent. Results of studies have shown that utilization of phenoxymethyl and phenyl residue for the structure optimization of 1,2,4-triazole $(4 H)$ scaffolds is an effective approach in novel anti-ulcer agents design and may be taken as the variant of hybrid pharmacophore approach.

\section{CONCLUSIONS}

Overall, this work illustrated that 4-phenyl5-4-(R)-phenoxymethyl-1,2,4-triazole-3-ylthio$1-\left(\mathrm{R}^{1}\right)$-acetophenones have been synthesized by alkylation of initial 3-mercapto-4- phenyl -5- phenoxymethyl -1,2,4-triazole with cloroacetophenones. 
The structure of substances synthesized have been proved by elemental analysis and spectral data. Potential anti-ulcer activity was found among new derivatives 1,2,4-triazole $(4 H)$. Compound $\boldsymbol{8} \boldsymbol{b}$ was substantially more active than others and requires further study. The studies confirmed compound $\boldsymbol{8} \boldsymbol{b}$ as a potent lead compound for drug discovery and further optimization.

\section{REFERENCES}

1. Mashkovskiy MD. Lekarstvennyie sredstva: 2 volumes. $14^{\text {th }}$ ed. Moscow: Novaya volna; 2000. Russian.

2. Bekircan O, Gomrbkзьoplu N. Synthesis of some 3,5-diphenyl-4H-1,2,4-triazole derivatives as antitumor agents. Indian Journal of Chemistry. 2005;44(10):2107-13.

3. Rakesh K, Shahar MY, Birendra S. Synthesis, characterization and biological evaluation of novel 1,2,4-triazole derivatives as potent antibacterial and anti-inflammatory agents. Der Pharma Chemica. 2014;6(1):137-43.

4. Sztanke K, Tuzimski T, Rzymowska J, et al. Synthesis, determination of lipophilicy, anticancer and antimicrobial properties of some fused 1,2,4-triazole derivatives. European Journal of Medicinal Chemistry. 2008;43(2):404-419.

5. Chelamalla R, Venkatesham A, Sarangapani M. Synthesis and Antidepressant Activity of Some Novel 1,2,4-Triazole Derivatives. Journal of Pharmacy Research. 2012;5(9):4739.

6. Ram JS, Dharmendra KS. Syntheses of Some 3,5-Diaryl-4H-1,2,4-triazole Derivatives and their Antifungal Activity. E-Journal of Chemistry. 2009; 6(1): 219-224.

7. Saidov NB, Kadamov IM, Georgiyants VA. The synthesis of new 3-phenacylmetylthio-4-aryl5-phenylaminomethyl-1,2,4-triazoles $(4 \mathrm{H})$ as potential neurotropic agents. Zh Org Farm Khim. 2013;11,1(41):44-48. Ukrainian.

8. Saidov NB, Kadamov IM, Georgiyants VA, Perekhoda LO. Synthesis, docking studies, and biological evaluation of anti-ulcer activity of 4-allyl-5-(4-R1)phenylthiomethyl-1,2,4-triazole-3-ylmercaptoacetic acid derivatives. Eur Chem Bull. 2014;3(5):466-471. Ukrainian.

9. Saidov NB, Kadamov IM, Georgiyants VA. Synthesis of the new biological active compounds among derivatives of 3-mercapto-4-benzyl-5-methoxyphe-
nyl-1,2,4(4H)triazole. Zh Org Farm 2012;10:25-28. Ukrainian.

10. Veber DF, Johnson SR, Cheng HY, et al. Molecular Properties That Influence the Oral Bioavailability of Drug Candidates. J Med Chem. 2002;45(12):2615-23.

11. PASS: Prediction of Activity Spectra for Substances. Available from: http:///www.ibmh.msk.su/pass. Russian.

12. RCSB Protein Data Bank. [Electronic resource]. Available from: http://www.rcsb.org

13. Strugatsky D, McNulty R, Munson K. Structure of the proton-gated urea channel from the gastric pathogen Helicobacter pylori. Nature. 2012;493:2-258.

14. Jegerschold C, Pawelzik S, Purhonen P. Structural basis for induced formation of the inflammatory mediator prostaglandin E2. Proc Natl Acad Sci USA. 2008;105:11110-5.

15. Okada T, Sugihara M, Bondar AN, et al. The retinal conformation and its environment in rhodopsin in light of a new 2.2 A crystal structure. J Mol Biol. 2004;342:571-583.

16. Scigress Explorer Ultra 7.7 Bio Applications Getting Started Manual, Fujitsu.

17. Abraham DJ. (ed.) Burger's Medicinal Chemistry and Drug Discovery, v.4 - Drug Discovery and Drug Development. 6th ed. A Wiley-Interscience Puplication, A John Wiley and Sons, Inc.; 2003.

18. Valle DL. Peptic ulcer diseases and related disorders. In: Braunwald E, Fauci AS, Kasper DL, Hauser SL, Longo DL, Jameson JL, editors. Harrison's principles of internal medicine. $16^{\text {th }}$ ed. New York: McGraw-Hill; 2005.

19. Breitmaier E. Structure elucidation by NMR in organic chemistry. $3^{\text {rd }}$ ed. Chichester: John Wiley and Sons Ltd; 2002. 